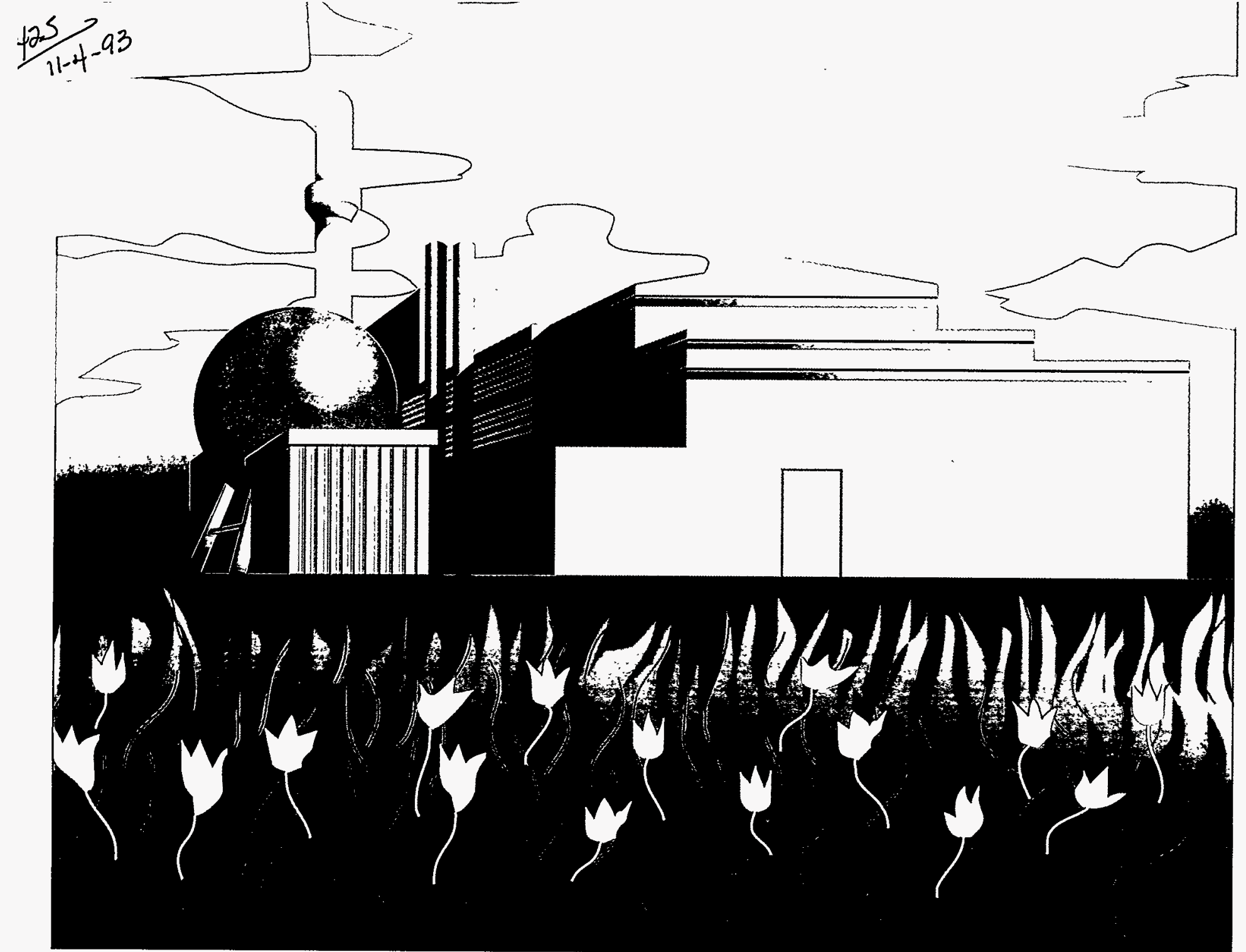

\title{
U.S. Department of Energy \\ Waste Material Management: Energy and Materials for Industry
}
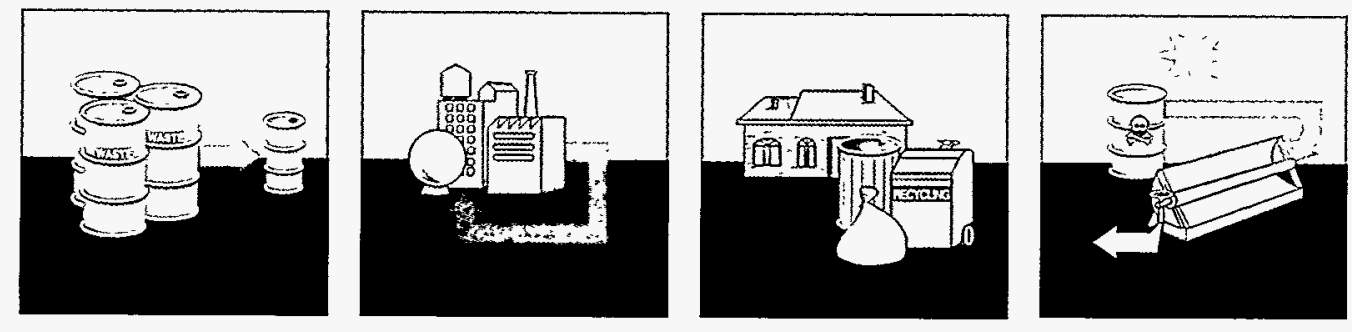

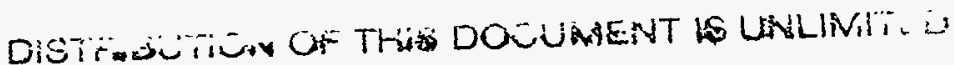




\section{DISCLAIMER}

This report was prepared as an account of work sponsored by an agency of the United States Government. Neither the United States Government nor any agency thereof, nor any of their employees, make any warranty, express or implied, or assumes any legal liability or responsibility for the accuracy, completeness, or usefulness of any information, apparatus, product, or process disciosed, or represents that its use would not infringe privately owned rights. Reference herein to any specific commercial product, process, or service by trade name, trademark, manufacturer, or otherwise does not necessarily constitute or imply its endorsement, recommendation, or favoring by the United States Government or any agency thereof. The views and opinions of authors expressed herein do not necessarily state or reflect those of the United States Government or any agency thereof. 


\section{DISCLAIMER}

Portions of this document may be illegible in electronic image products. Images are produced from the best available original document. 


\section{The Waste Material Management Division}

U.S. industry spends more than $\$ 45$ billion each year to handle, clean, and dispose of hazardous waste materials. The total cost for disposal of nonhazardous wastes is unknown, although one estimate for municipal wastes would add more than $\$ 8$ billion to the bill.

Yet industrial and municipal wastes actually represent a reservoir of potential energy and material supply. The energy embodied in waste materials, combined with the energy used in their control and cleanup, amounts to as much as $10 \%$ of the energy our nation uses each year. By minimizing or reclaiming these wastes, we could redirect the energy, material, and economic investment in waste management to more productive uses.

Transforming wastes from a treatment problem to an energy and economic opportunity requires innovation at every stage of product design, manufacture, consumption, and disposal. The U.S. Department of Energy (DOE), through its Waste Material Management (WMM) Division, is collaborating with industry to develop the knowledge and technologies necessary to enable this transformation to take place.

The potential payoff is huge. By reducing the quantities of wastes generated and reusing or converting those that are generated, industry can enhance its competitive edge, and our nation can save energy and better protect the environment.

This booklet describes the Waste Material Management programs, which are designed to help tap the potential of waste materials. Each of the programs has a unique and vital relationship with industry. By working together, $\mathrm{DOE}$ and industry are turning the challenge of waste material management into the reality of a cleaner, more energy-efficient economy.

\section{MASTER}




\section{Industrial Waste Streams}

\section{Total: 11 BAllion Metric Tons (12 Billion Tons)}

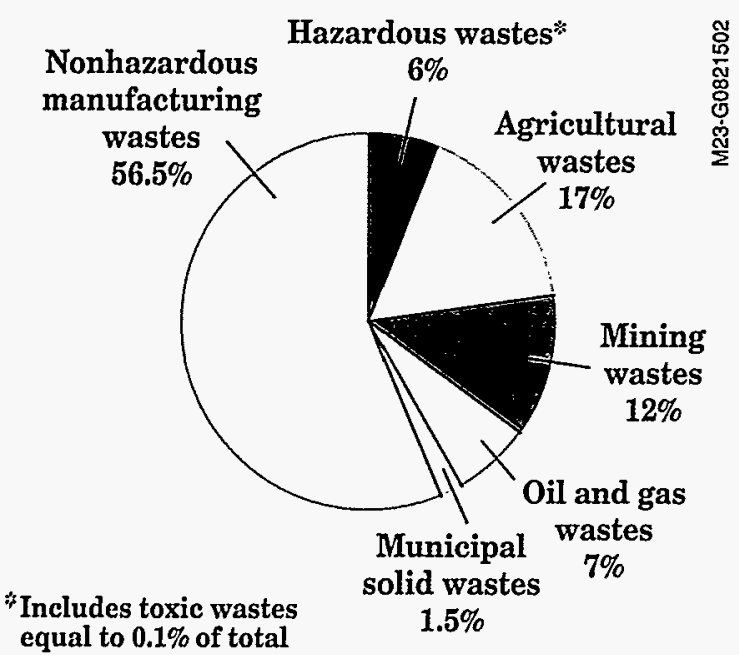

Source: Energetics, Inc., 1992

\section{The DOE Program}

DOE's Office of Industrial Technologies is working with industry to develop waste management practices that make more efficient use of energy, materials, and money. Working within the framework of the National Energy Strategy, the office's Waste Material Management Division seeks to

- Find and promote cost-effective ways for industry to reduce or minimize wastes or utilize them as raw materials, fuels, or energy

- Enhance fuel flexibility, including the increased use of renewable fuels and feedstocks and of MSW

- Provide information about the options available for improving energy efficiency using costeffective waste management technologies.

The WMM Division sponsors four programs aimed at developing the waste management technologies that industry needs: Industrial Waste Reduction (IWR), Waste Utilization and Conversion (WUC), Energy from Municipal Waste (EMW), and Solar Industrial Applications (SIA). These programs work closely with each other, with other parts of DOE, and with the other federal agencies involved in waste management research to make sure their activities are complementary.

DOE's Albuquerque Field Office and four national laboratories-Argonne National Laboratory, Los Alamos National Laboratory, the National Renewable Energy Laboratory, and Sandia National Laboratories-provide program management support to Headquarters. Albuquerque and the laboratories execute the research either in-house or through subcontracts to industry, universities, or other organizations.

Each of the programs has a strong link with industry. Through industry review boards, independent analyses, and open solicitations to industry, program managers tailor the research to respond to industry's needs. A special emphasis is placed on sharing project costs with industry. In this manner, DOE leverages the federal investment and involves industry directly in research, providing a direct path for technology transfer.

Waste Material Management Programs

FY 1993 Funding

Program

\$in millions

Industrial Waste Reduction

$\$ 10.8$

Waste Utilization and Conversion

Energy from Municipal Waste

Solar Industrial Applications

Total

$\$ 29.2$ 


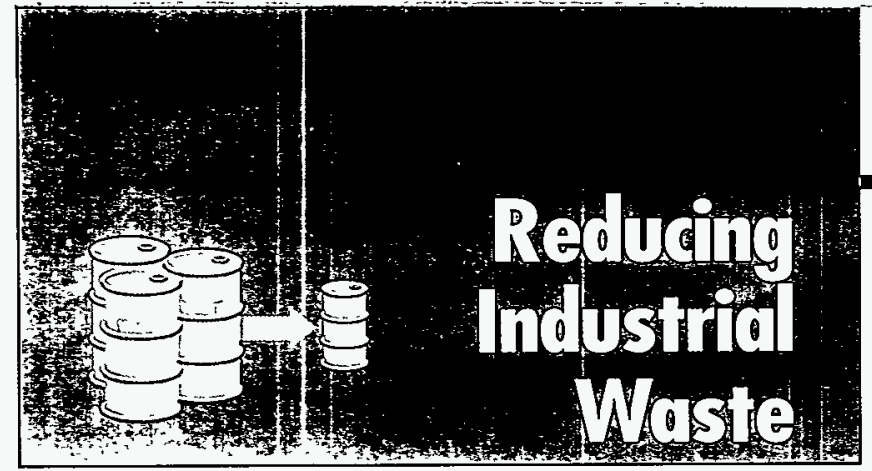

Mission: To work with industry to develop and commercialize cost-effective technologies and practices that will save energy by reducing waste.

Perhaps the most effective and economical method of waste management is waste reduction. Known also as waste minimization, waste reduction involves reducing or eliminating waste at its source-usually as part of a production

"3M has been pursuing waste minimization through our Pollution Prevention process-therePays program for more than 16 years. Since 1975, 3450 separate projects have prevented over 1 billion pounds of pollution annually and saved $\$ 575$ million." by reducing requirements for treatment and disposal. Waste reduction saves the energy and financial costs associated with

- Robert P. Bringer, 3M Company waste treatment and the energy used to

produce the raw materials and products. It can also lead to increased productivity, because more raw material becomes product.

In the mid-1970s, many companies began to recognize the value of minimizing wastes and, since then, have made great progress in their plants. But much of this attention has focused on the financial, environmental, and public relations benefits of minimizing wastes. Few programs have focused specifically on the potential energy savings.

These energy savings could be significant, however. In fact, reducing industrial waste by $50 \%$-an aggressive but achievable goal-would save enough energy to supply about 30 million homes.

The DOE Industrial Waste Reduction Program focuses on this inextricable link between waste reduction and energy savings. By targeting the industries and processes that use the most energy and generate the most wastes, the program can have the greatest impact on energy efficiency.

Relatively new as a formal program, the waste reduction activities are structured around five key elements that build on the progress industry has already made (see below). These activities are designed to help industry overcome the remaining obstacles to waste reduction, which include

- The large number of unique industrial processes, each requiring individual solutions

- A shortage of readily available information on recent developments in waste management and their potential cost savings

- A shortage of private money for research and development $(R \& D)$ on process and product redesign

- The risks to industry associated with implementing process and product changes.

\section{Industrial Waste Characterization}

The lack of comprehensive, consistent data on the quantity, nature, and source of industrial waste streams is a fundamental problem in identifying opportunities in waste reduction. Most of the data that exist are collected in the context of compliance with environmental regulations. As such, the data tend to describe toxic waste discharges,
Key Elements of the Industrial Waste Reduction Program

- Industrial waste characterization

- Opportunity assessments

- Technology research and development

- Technology and information transfer

- Institutional analysis rather than

waste generation. Without comprehensive data on waste generation, targeting waste reduction $R \& D$ is difficult to do effectively. 


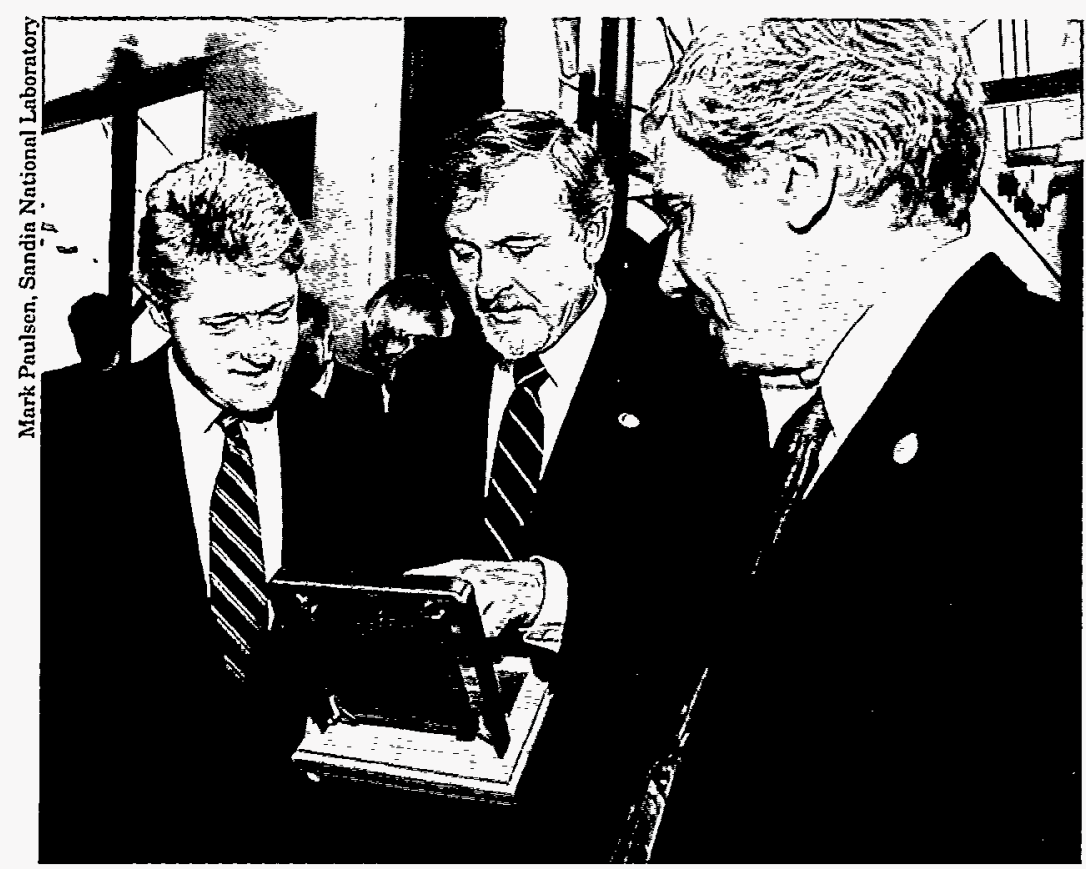

President Bill Clinton receives the first no-clean soldering circuit board during a visit to Sandia National Laboratories. The new no-clean process eliminates the need for CFC solvents to clean soldering residues from electronic assemblies. seeking expert advice from industry, government, and academia, program managers can identify the industries and processes with the greatest potential for waste reduction and energy savings. Armed with this information, program managers then typically issue solicitations for industry to submit proposals for cooperative research projects. In this manner, the needs and interests of industry drive program research.

For example, one recent study looked at opportunities for waste reduction in the chemical manufacturing industry. Part of the project involved a workshop in July 1991 that was attended by high-level executives of chemical companies to discuss the needs of industry. The group identified the need for new
To fill this information gap, the program is working with industry and other federal agencies to collect and review existing data bases, reconcile differences among them, and, where possible, standardize the data. The goal of the program is to obtain or develop data that reflect waste generation, rather than discharges. One specific project is being cosponsored by the Department of Commerce to study the expenditures for energy and pollution control associated with each of the products represented by the 5-7 digit Standard Industrial Classification codes.

As the data on waste generation become available, they will form the basis of studies that identify R\&D opportunities in various industries. The data will also be useful to industries directly as they pursue waste reduction opportunities on their own. The same information is essential to planning the Waste Utilization and Conversion Program.

\section{Opportunity Assessments}

Analytical studies of the opportunities for waste reduction help direct the research of the Industrial Waste Reduction Program. By analyzing the available data on industrial waste practices and technologies for separations, reactions, and controls for waste reduction. The program responded with a solicitation for cooperative $R \& D$ with industry in the fall of 1991. Negotiations are now under way with three firms selected for possible awards.

The next study will extend the focus on chemical producers to chemical users. As in the previous study, program managers will sponsor a workshop with industry

\section{Strategies for Reducing Industrial Wastes}

- Improve operational efficiency

- Recycle wastes within the process

- Redesign the production process

- Use alternative feedstocks

- Redesign the product for more effective use of raw materials representatives to determine the needs for research and development. The results of this opportunity assessment may lead to another solicitation to industry. 


\section{Technology Research and Development}

Research and development projects form the core of the program. Projects are chosen according to their potential for saving energy, reducing wastes, lowering costs, and providing the greatest national benefit per DOE dollar. Other critical factors include the degree of industry support and the need for government funds. Projects are designed to involve one or more industrial partner throughout the process of basic research, laboratory tests, field tests, and in some cases, pilot tests. Typically, the level of industry's involvement and cost-sharing increases as the technology nears commercial readiness, but the level must average at least $50 \%$ over the course of the project.

\section{Resonant Cavity Milcrowave Applicator}

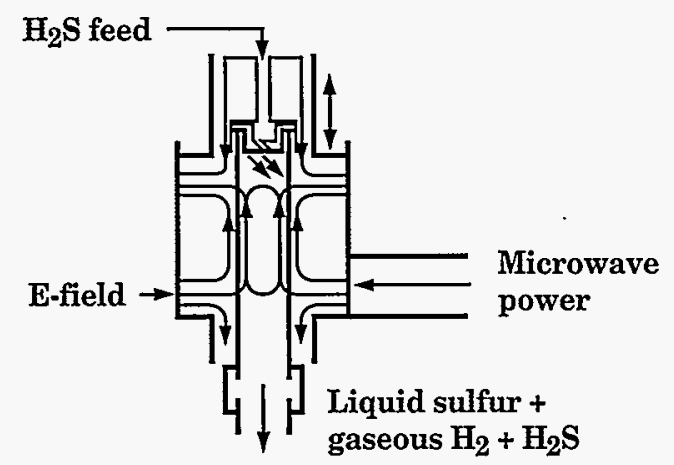

Source: Argonne National Laboratory

Argonne National Laboratory is leading a task to recover the hydrogen sulfide generated in petroleum refining and natural gas production. The system uses a microwave reactor to split the gas into hydrogen and sulfur.

Several current projects focus on recovering or reducing emissions of waste gases. For example, one project cosponsored by Dow Corning has developed new technology for the silicon industry that replaces conventional open-hearth furnace technology with a new closed furnace. The new furnace, now being tested at a pilot plant, dramatically reduces energy use and emission of silicon dioxide, and could help the U.S. silicon industry regain its competitive edge against low-cost imports. Another project involves conducting laboratory research on a technique for recovering hydrogen and sulfur from the hydrogen sulfide generated from petroleum refining and natural gas production.

Other projects target reduction of solvent use, which would lower emissions of volatile organic compounds into the atmosphere. For one of these projects, DOE teamed with the 3M Company to develop coatings that use photocatalytic curing systems instead of solvents. The new coatings have large potential applications in the aerospace industry and in tape manufacturing. Another solvent project resulted in the formation of the Joint Association for the Advancement of Supercritical Fluid Technology, a consortium of industry partners. The partnership is developing precision cleaning techniques that don't use chlorofluorocarbons or other chlorinated solvents.

The IWR Program has also joined forces with the Environmental Protection Agency (EPA) and the U.S. Department of Commerce in a program called NICE 3 (National Industrial Competitiveness through Environment, Energy, and Economics). Begun as a pilot program in FY 1991, NICE ${ }^{3}$ cosponsors research with industry to demonstrate new technologies that prevent pollution and improve energy efficiency, identify barriers to industrial pollution prevention techniques, and develop strategies to overcome these barriers. In FY 1993, the program is being jointly funded by EPA and DOE and is targeting the chemicals, petroleum, primary metals, and paper industries.

\section{Technology and Information Transfer}

Industry involvement in all aspects of the IWR program forms the cornerstone of the program's technology transfer. By tailoring activities around the needs of industry, involving it in collaborative R\&D, and conducting field tests in operating plant environments, the program ensures that new technologies will be adopted rapidly by the private sector. Industry involvement takes various forms, including contract research, grants, and cooperative research and development agreements (CRADAs). 
Besides interacting directly with industrial partners, program managers are developing a comprehensive plan for technology transfer that will integrate various methods of communicating with the industrial community. These methods include

- Publishing fact sheets, brochures, and reports

- Preparing slide or video presentations

- Disseminating data bases

- Conducting workshops and contractor review meetings

- Giving presentations

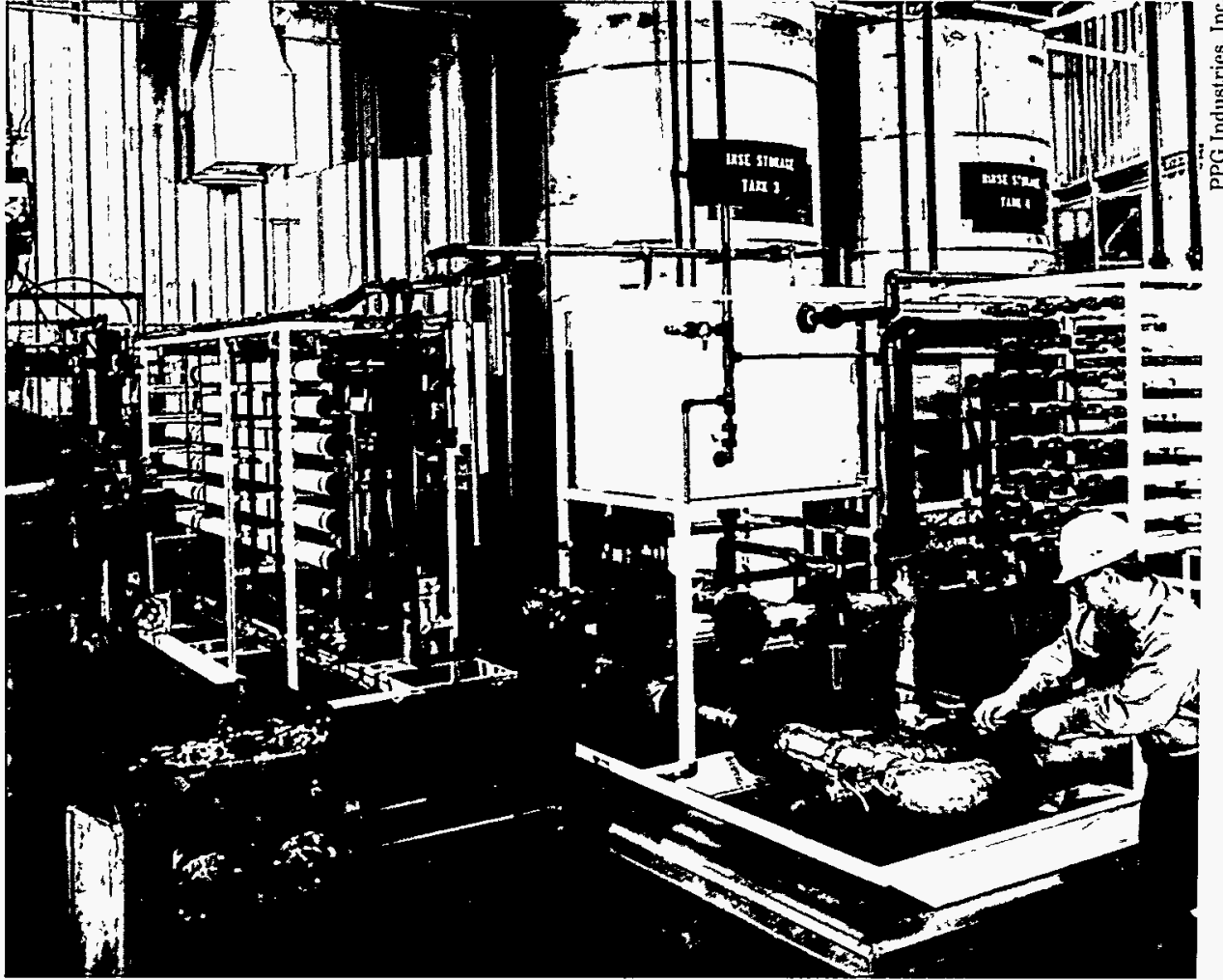

This unit, developed by PPG Industries, Inc., recovers cleaning waters containing water-based coatings. The project is part of the NICE ${ }^{3}$ program sponsored by DOE and the Environmental Protection Agency. at technical conferences

- Publishing articles in technical and trade journals.

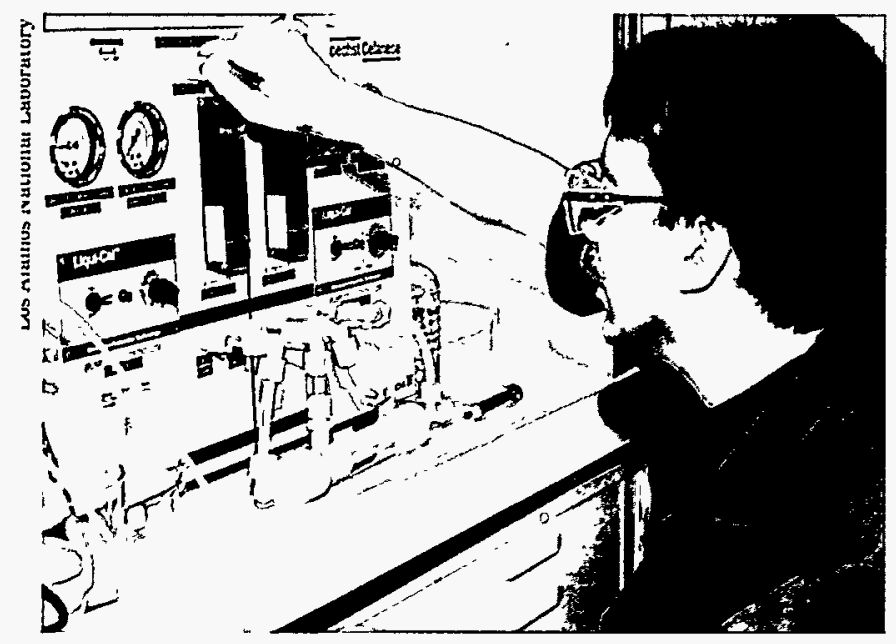

Working with the Boeing Company, scientists at Los Alamos National Laboratory are developing a process to recycle metal ions from electroplating wastes.

\section{Institutional Analysis}

The program also addresses the nontechnical factors that sometimes affect decisions to implement new technologies. Some of these factors relate to the financial and structural aspects of industry, such as the cost of capital, macroeconomic factors, size of companies, and industry-specific competition. Additional constraints may include regulatory requirements, liability concerns, corporate philosophy, market conditions, and product specifications.

Understanding these issues is vital to developing an effective and realistic program plan. The program examines these issues in studies conducted collaboratively with industry and in close coordination with the opportunity assessments. One such study was completed in FY 1992; it examined the incentives and disincentives to waste reduction created by the current legislative and regulatory climate. The report reflects input from several trade associations and individual industrial firms. 


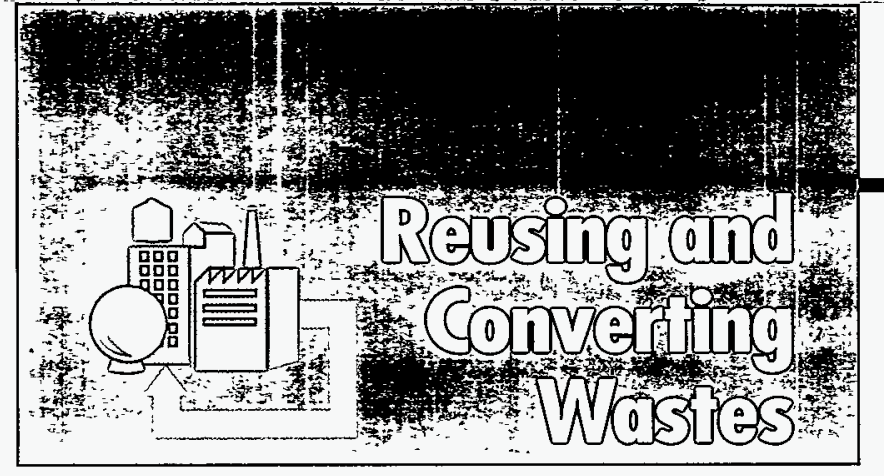

Mission: To work with industry to develop economical and environmentally acceptable technologies for utilizing industrial and postconsumer wastes as feedstocks or converting them to fuels.

No matter how successful industry and consumers become at minimizing wastes, some generation is inevitable. Industrial processes will always produce some by-products; industrial and consumer products will eventually wear out. Disposing of these materials through conventional means of treatment, storage, or landfilling may harm the environment and wastes their potential energy and economic value.

Increasing disposal costs for wastes have begun to create a market for waste materials. A waste stream from one industry can become a feedstock for another. In

\section{'Basic research at a DOE lab, combined with our engineering development, has created a business in recycling galvanized steel potentially worth $\$ 2$ billion annually by 2000, with the accompanying benefits of energy and raw materials conservation."}

- Bill Morgan, Metal Recovery Industries, Inc., U.S.A. fact, several organizations called "waste exchanges" have been formed around the country to facilitate the exchange of waste materials between companies. In general, these agencies publi- cize available materials and coordinate the transfers, but do not actually handle the wastes themselves. Waste transfers typically involve solvents, oils, acids, and other specialty materials.

Recycling on the consumer level is another part of the waste management solution. About $17 \%$ of MSW is recovered for recycling or reuse today, and curbside recycling programs are growing at an impressive rate. However, the effectiveness of this route is directly affected by the cost-effectiveness of the reprocessing technologies and the availability and proximity of markets for the recycled materials.

To fully exploit the energy and materials resource embodied in industrial and consumer wastes will require new technology. DOE's Waste Utilization and Conversion Program is designed to work with industry to develop the needed technologies. By doing so, the program can help industry remain competitive and enhance the energy efficiency and environmental quality of our nation.

The WUC program has

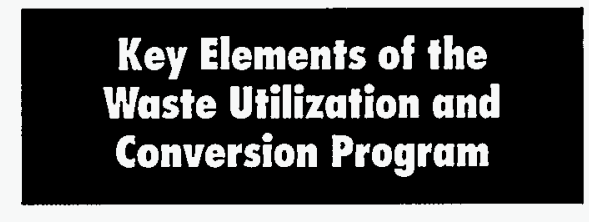

- Technology research and development

- Pilot and demonstration projects

- Technology transfer

- Technology and data assessment four basic

elements. Similar in approach to the Waste

Reduction Program, this program begins each new area of research with an analysis of the particular waste stream and its potential for conversion or utilization. With help and advice from industry experts, analysts estimate the potential net energy benefit and identify needed R\&D. Program managers can then select projects with the greatest potential for success and for energy and cost savings.

\section{Technology Research and Development}

The technical element of the WUC program aims to develop new technologies for reusing waste materials that offer high pay-off in the mid- or long term. The preferred path for conducting these R\&D projects is a cooperative effort involving one or more industrial partners teamed with DOE laboratories or university research centers. Experience has shown that these teams are the most successful in developing cost-effective, practical technologies and transferring them to industry. 
Research currently sponsored by the program is broad-based. The selection of topics and projects is guided by the same set of criteria considered by industry in deciding whether to institute a particular waste conversion strategy. Both program managers and industrial waste managers ask the following questions:

- Is there a market for the resulting product?

- What is the product's value?

- Is there a good match between the optimal scale of the conversion process and the size of the available waste streams?

- Are there increasing disincentives to the current practice?

- What new technology is required?

A major focus of the technical program is materials separation and recycling. Several projects address recovery and utilization of metals, including galvanized steel scrap, scrap aluminum, and "red metal," the copper alloys used to make faucets, valves, and other plumbing fixtures. These projects are cost-shared with individual companies or industrial trade groups. Other projects target postconsumer goods such as plastics,

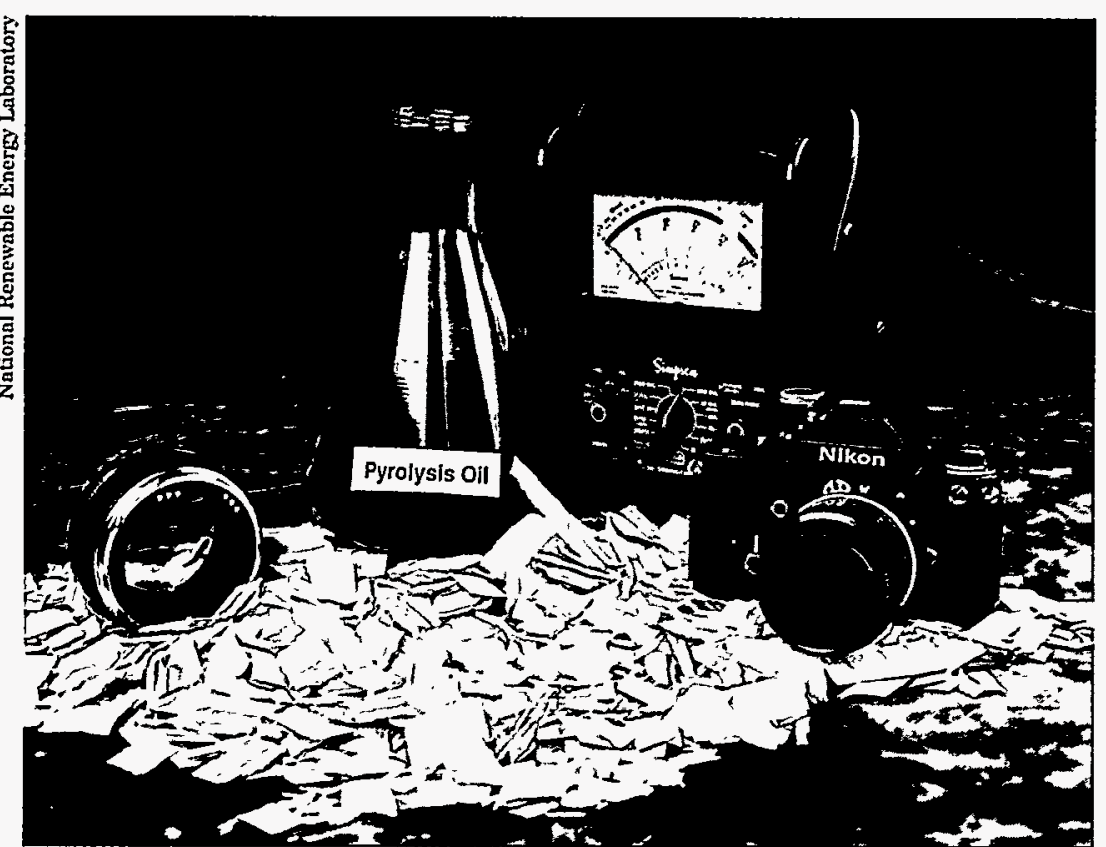

Scientists at the National Renewable Energy Laboratory have developed a process to make adhesives and resins from waste wood. These resins can replace petroleumbased resins in molding compounds. waste tires, and waste carpet.

The program is also developing technologies for converting waste components to higher value materials. For example, scientists at Argonne

National

Laboratory can now convert potato wastes to biodegradable plastics. Plastics made by the process are now being tested by potential users. In another project researchers developed a continuous fermenterseparator for producing ethanol from food processing wastes. Conducted at Purdue University, the project was cost-shared by several corporate sponsors, including Kraft General Foods, Inc.; Catalytics, Inc.; Permeate Refining, Inc.; and the Wisconsin Milk Board.

An investigation into "design for recyclability" is an emerging IWR project. The concept involves designing products and manufacturing processes in such a way that eventual recycling of the product becomes easier and cheaper. A joint project with the Bureau of Mines will identify materials not being recycled, determine the constraints to recycling, and evaluate possible design changes to make recycling easier.
Strafegies for Reusing Industrial Wastes

- Separation and recycling

Conversion to reduce toxicity

- Remanufacture to reassemble discarded goods and new parts

- Demanufacture to disassemble discarded products for further

- Direct conversion to energy through combustion or catalytic

- Remining or extraction to recover valuable materials from discards

m




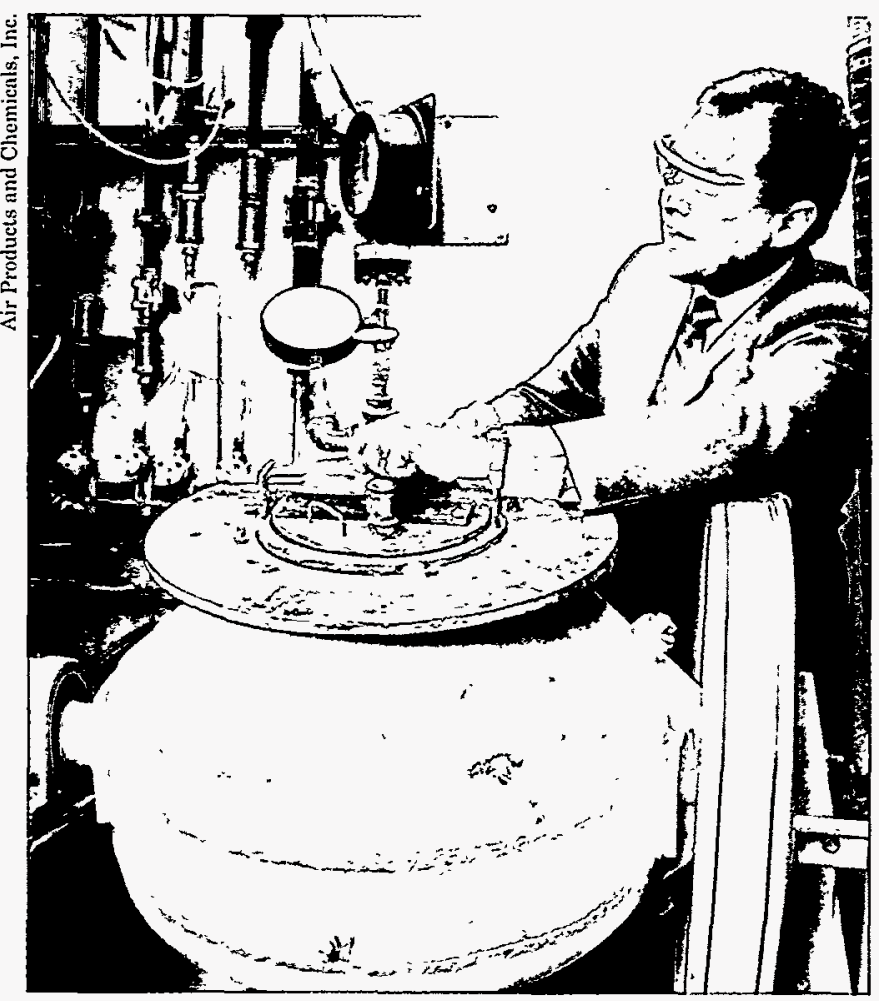

Air Products and Chemicals, Inc. developed a batch reactor to treat scrap tire rubber. The reactor modifies the rubber's surface, allowing it to be mixed with polymers to form composite materials.

\section{Pilot and Demonstration Projects}

Pilot-scale or demonstration projects play a key role in technology development. Successfully demonstrating new technologies at a large scale eliminates some of the risk industries face in adopting new technologies. These demonstration projects offer a prime opportunity for industries to share the costs and minimize the risks associated with innovation.

Several WUC projects are in the demonstration project stage. One involves a new process for removing zinc from galvanized steel scrap. Jointly sponsored by Metal Recovery Industries, Inc., a pilot plant for this technology is nearing completion in East Chicago, Indiana, under the metals initiative program. Also ready for pilot-scale testing is the process for converting food wastes to ethanol. A third project, cosponsored by Manville Sales Corporation, tested a process for reusing asphalt shingle manufacturing waste in a full-size commercial roofing plant. This technology is now ready for commercial application.

\section{Technology Transfer}

Like the Waste Reduction Program, the WUC program places a strong emphasis on working closely with industry. Many times the industrial partners are potential users of the technology and put it immediately into action. Other times partners are companies that might license the technology and market it to industrial users. Either way, these partners offer an effective mechanism of technology transfer.

The program also employs other mechanisms to reach a broader audience of potential users. Chief among the techniques are publishing papers, journal articles, and brochures, and attending trade fairs and exhibits. Program managers maintain lists of appropriate industry representatives and keep them informed of activities. The program also sponsors review meetings and workshops that are open to the public.

\section{Technology and Dafa Assessments}

Assessments of the needs and practices of industry and the opportunities for R\&D help guide program activities. One study currently under way focuses on metals recycling. Working closely with industry, program analysts are examining opportunities such as recovery of iron from baghouse dust. Results of this and other studies will help program managers target future initiatives in R\&D. 


\section{Reclaiming Postconsumer Wastes}

Mission: To ensure that economic and environmentally sound options are available for productively using municipal waste.

In 1990, Americans discarded 180 million metric tons (196 million tons) of waste to municipal facilities (estimates range up to 240 million metric tons [270 million tons] for residential, commercial, and institutional waste) with an energy value of as much as $4 \%$ of our nation's

"The key to sound waste management policy is to ensure that cities and towns have an integrated program of source reduction, recycling, waste-to-energy plants, and landfills using state-of-the-art environmental systems."

- Edgar Berkey, National Environmental Technology Applications Corporation, University of Pittsburgh annual energy consumption. Some of this energy is reclaimed through recycling and waste-toenergy conversion. However, the bulk of municipal solid waste, about $67 \%$, is buried in landfills,

taking its energy and material value with it. Although programs aimed at reducing the generation of wastes should slow the growth rate of MSW, its disposal will continue to be an issue far into the future.

At the local level, managing MSW has become one of the most controversial environmental issues facing communities. The best approach to municipal solid waste management is a coordinated one that combines four options: source reduction, recycling, conversion to energy, and landfilling. The ideal mix of options for any particular location depends largely on local conditions: the cost and availability of landfills, accessibility to recycling facilities and markets for recycled products, the cost and environmental requirements of converting waste to energy, municipal budgets, and public concerns.
As an energy resource, MSW is unique. It can produce energy through combustion or other conversion processes, and it can save energy by displacing virgin material feedstocks through recycling. It can also improve the environment by reducing the amount of wastes that must be landfilled and displacing emissions from other resources.

A significant industry already exists in our nation for converting MSW into energy. About 140 waste-toenergy plants are operating today with a combined electricity-generating capacity of more than 2400 megawatts, which displaces about $0.4 \%$ of our fossil fuel use. Some of these plants burn MSW directly. Others use a solid fuel called refuse-derived fuel made by reducing the particle size of MSW; removing the metals, glass, and other inorganic materials; and, sometimes, forming the remaining combustibles into pellets or briquettes. The refuse-derived fuel is then burned in dedicated boilers or in existing coal-fired boilers, displacing some of the coal. Another group of plants collects the methane-rich gases generated within existing landfills to use as fuels or substitutes for

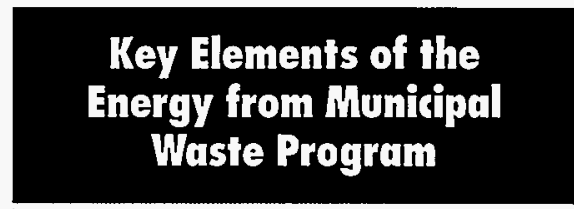
natural gas.

The potential for growth in the waste-toenergy industry is great.

- Data collection and analysis

- Technology development

- Institutional assessments

- Technology and information transfer

Additional

plants either planned or under construction could add another 1800 megawatts of electric capacity. The National Energy Strategy predicts that wasteto-energy plants could eventually contribute about 2.2 exajoules ( 2.1 quadrillion Btu) of energy by 2010 , more than 6 times today's level.

To harness this source of energy, data on the energy, economic, and environmental aspects of the MSW management options are needed. Without good data, officials and the public find it hard to make complete and informed decisions on which options to choose. In addition, some institutional barriers 
inhibit investment in conversion plants. For example, the air emission standards governing waste-toenergy plants are more stringent than those for fossil-fuel-fired plants. And 4 years of research indicate that the quality of leachate from ash monofills approaches drinking water standards. Yet some people still question the environmental risks posed by ash and gaseous emissions produced by waste-toenergy plants.

The DOE Energy from Municipal Waste Program focuses on converting the MSW resource to energy and using it productively in recycled products. The program's goal is to provide the science, technology, and information necessary for municipal waste managers to design coordinated, cost-effective MSW programs that will be acceptable to the public. The key elements of the EMW program include data collection and analysis, technology development, institutional assessments, and technology and information transfer.

\section{Data Collection and Analysis}

One objective of the program is to collect a comprehensive set of consistent and reliable data on municipal waste and waste disposal options. The data should allow decision makers to compare alternative MSW management options with full consideration of their energy, environmental, and economic effects on individual situations.

To collect the data, the program researchers are working with industry and other federal agencies, in

\section{Destination of MSW}

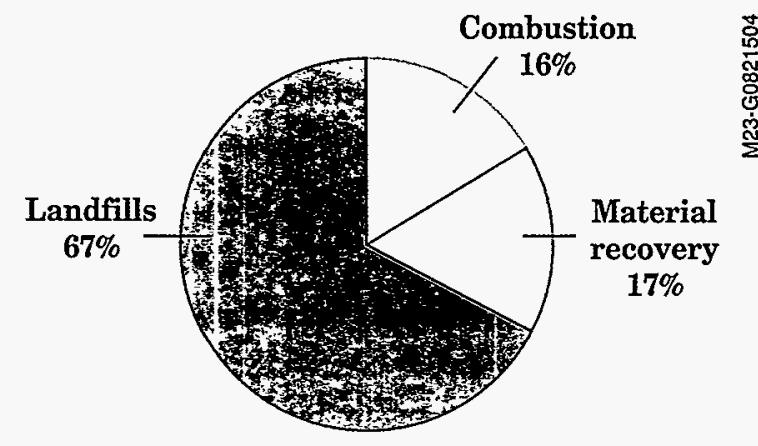

Source: EPA, 1992 particular EPA, to review existing published data, analyze these data to assess their credibility, and reconcile differences where they exist. In many cases, the data do not exist-for example, energy and environmental effects of recycling paper, glass, and other Strategies for Managing Municipal Solid Waste

waste streams

have not been quantified. This

- Reduce at source makes it difficult to compare the various
- Recycle

- Convert to energy

- Bury in landfills alternatives

available to a municipal solid waste manager on a uniform basis. This element of the DOE program is collecting data from materials recovery facilities, combustion plants, integrated waste management systems, and recycling facilities for newsprint and glass. Researchers are also acquiring data from other nations to allow examination of their approaches to waste management.

As these data become available, they are provided to solid waste managers and other decisionmakers at all levels of government (federal, state, county, and city). Data are also provided to industry so that it can develop systems for more energyefficient use of the MSW resource without adversely affecting the environment.

\section{Technology Developmenł}

MSW can be transformed into several forms of useful energy or energy-conserving products. These transformations take place in three types of processes: material recovery and reuse (recycling), thermochemical conversion, and biochemical conversion. The program is addressing each of these areas.

Material recovery and recycling in the states is growing. Yet the energy and environmental impacts of these facilities are not understood. As data become available, the program will begin technology development projects to make these facilities energy efficient and capable of using separated materials economically. 


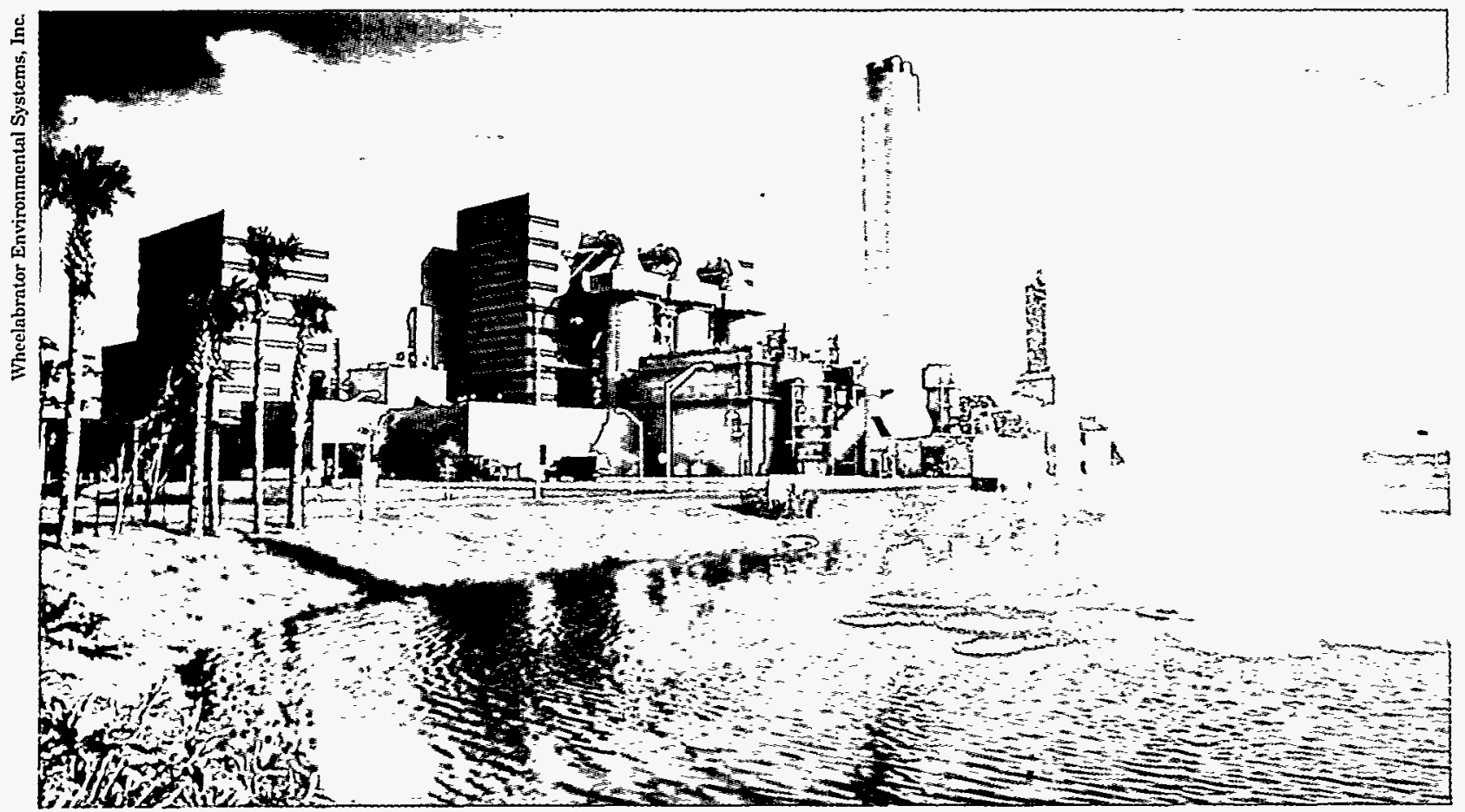

This 60-megawatt waste-to-energy plant in Pompano Beach, Florida, processes 2040 metric tons (2250 tons) of trash per day. The DOE program is working with industry to resolve issues of ash disposal and pollution control from plants.

Thermochemical processes for recovering the energy value of MSW use heat to break down the organic constituents. Researchers are evaluating techniques for reducing emissions from combustion plants by using low-cost methods of sorbent injection of MSW. Another project targets cocombustion of MSW (up to $30 \%$ by weight) with coal to determine the effect on emissions and ash residues. Cocombustion of MSW with sewage sludge is also being investigated. All these projects are cost-shared with industry.

Biochemical processes use microorganisms or enzymes to break down larger organic molecules into energy products. These processes operate at milder conditions than do thermochemical processes, but they require reaction times of several days or longer to complete. The program sponsors research on landfill gas production; this work focuses on gas migration and fugitive emissions. Researchers are also conducting laboratory research on high-solids anaerobic digestion and codigestion of sewage sludge with the organic fraction of MSW. No commercial facility for anaerobic digestion exists in the United States, although some pilot systems have been evaluated in the past. A project to develop and operate a demonstration-scale system for anaerobic digestion is being pursued. The project will link program researchers, private industry, and a host community to obtain data for future commercial development of this promising technology.

\section{Institutional Assessments}

Two issues in particular have an enormous impact on the construction of energy conversion plants. First, a large body of environmental regulations results in a lengthy, difficult permitting and siting process. Second, because these plants are capital-intensive investments, financing is difficult.

The program is analyzing these institutional barriers to develop solutions that allow utilization of the MSW resource. Program analysts are examining existing and pending legislation at federal and state levels to determine its effect on energy production and the MSW management industry.

\section{Technology and Information Transfer}

Effective technology and information transfer is critical to the success of the EMW program and the waste management industry. Inaccurate and 
incomplete data reinforce the many misconceptions about the relative costs and benefits of MSW options and technologies, and these misconceptions sometimes drive the decision-making process.

To provide industry and the public with current, credible information, the program is enhancing its information transfer program in cooperation with the EPA and appropriate industry associations. This effort will use a variety of tools to communicate with the MSW community and the public, such as

- Publishing fact sheets, brochures, and case studies

- Preparing and presenting slide shows or videos

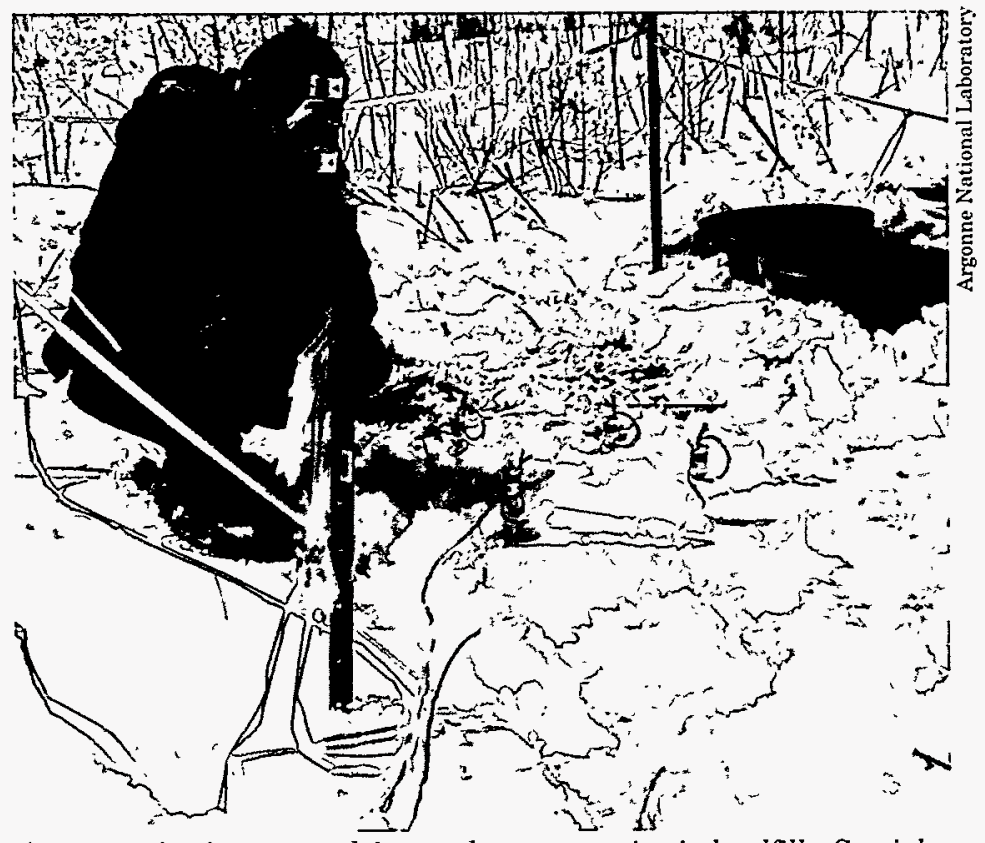

Argonne scientists are studying methane generation in landfills. Special probes are inserted to measure the gas pressure within the landfill.

- Disseminating data

- Conducting conferences, workshops, and educational programs

- Hosting contractor review meetings

- Presenting papers at technical conferences

- Publishing articles in technical and trade journals.

In addition, as results of the program's Data Collection and Analysis element become available, program managers will package and disseminate this information to those responsible for decisions on waste management. Finally, the program will work with its industry partners and contacts to make sure new technologies are made available to the companies that can use them.

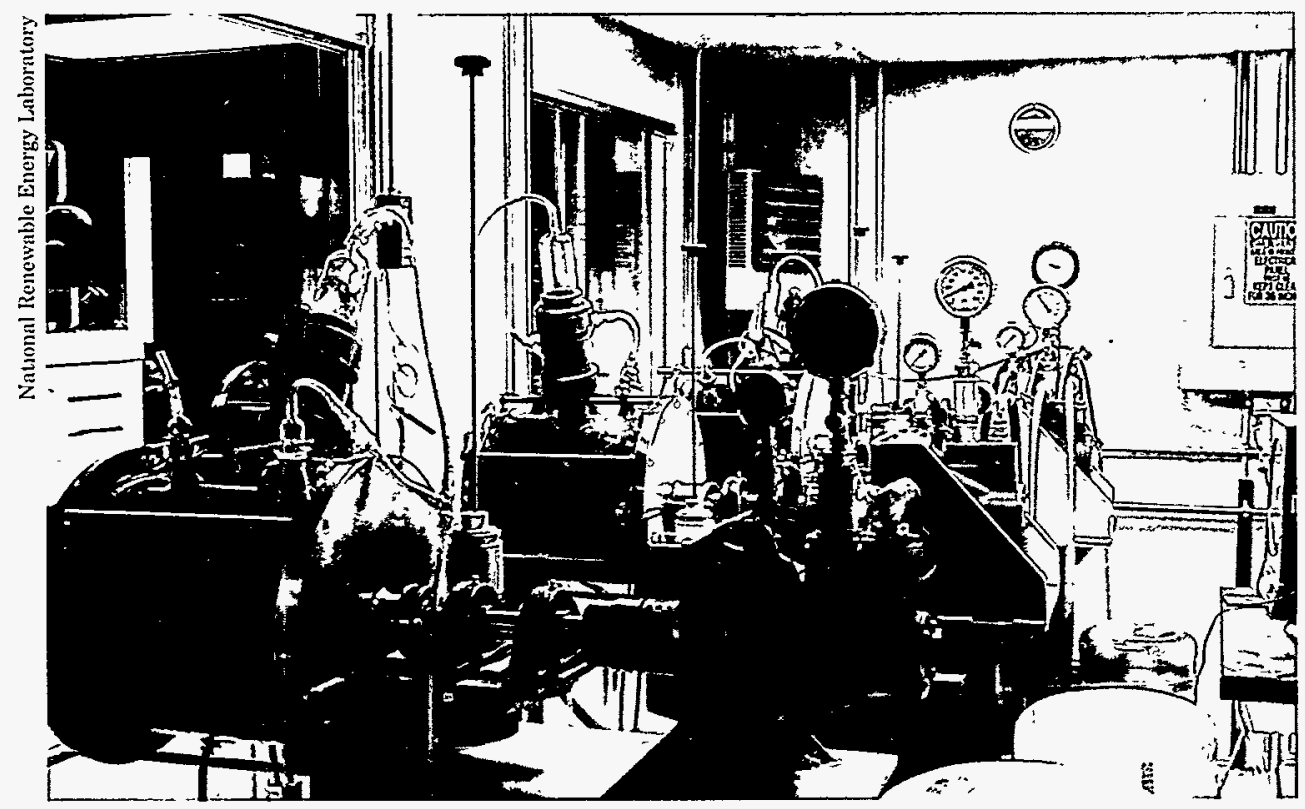

A new design for a high-solids reactor was developed at the National Renewable Energy Laboratory. The reactor converts MSW to high concentrations of methane. 
Unlike the one-step water process, soil detoxification is a two-step process. First the soil is heated to vaporize the organic contaminants. This concentrated waste stream is then exposed to sunlight

Mission: To develop and adapt solar technologies for use in industrial applications to increase fuel flexibility, reduce energy costs, and decrease environmental impacts.

American industry generates about 650 million metric tons ( 720 million tons) of hazardous wastes each year. Less than one-tenth of these wastes is destroyed; the remainder must be stabilized in some manner for permanent storage or disposal. There are

$\begin{array}{ll} & \text { also } 28,000 \\ \text { "Solar detoxification has } & \text { sites nation- } \\ \text { great promise for decon. } & \text { wide with } \\ \text { taminating vapor and } & \text { contaminated } \\ \text { aqueous waste streams. We } & \text { soil or water } \\ \text { hope to commercialize the } & \text { that must be } \\ \text { process for uses ranging } & \text { remediated. } \\ \text { from waste cleanup to } & \text { Cleaning up } \\ \text { quality control of indoor } & \text { these wastes by } \\ \text { air." } & \text { conventional } \\ \quad \text { - Jim Friehaut, } & \text { methods- } \\ \quad \text { United Technologies } & \text { incineration, } \\ \quad \text { Research Center } & \text { air stripping, }\end{array}$
concentrated up to 1000 times. The infrared and visible parts of the spectrum heat the waste to $700^{\circ}-1000^{\circ} \mathrm{C}$; the high-energy ultraviolet light then destroys the molecules. Alternatively, the concentrated stream of contaminants can be treated at lower temperatures with lower concentrations of sunlight. This

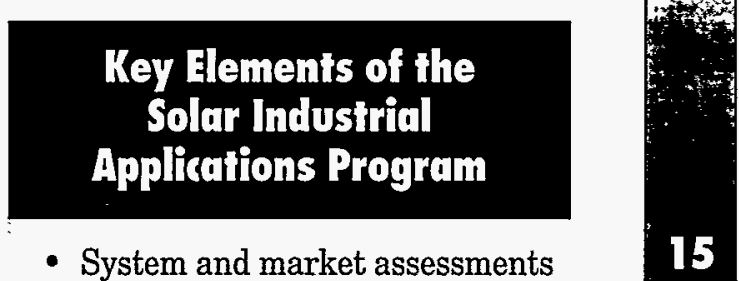
process involves shining ultraviolet light on a catalyst, which initiates the destruction of the chemicals.

Solar detoxification is just one of the possible applications of solar energy to meet industrial needs. It can also provide thermal energy to displace the $30 \%$ of the total primary energy used in the industrial sector for process heat. The technology has already been demonstrated for heating air or water directly or for heating a working fluid that can be stored for later use. Commercial applications have included steam generation at up to $315^{\circ} \mathrm{C}$; laboratory systems have generated temperatures up to $1500^{\circ} \mathrm{C}$. Although technical performance of these systems has been dramatically improved compared with that of the early systems installed in the $1970 \mathrm{~s}$, substantial market barriers continue to inhibit widespread application.

Scientists are exploring another area of application-advanced materials. Using solar furnaces that concentrate sunlight up to 50,000 times, researchers are exploring the possibilities of making advanced materials such as diamond-like carbon films, submicron ceramic powders, and high-quality superconducting films. 
Using solar energy for these applications offers industry several advantages. First, solar systems can help industry become less dependent on fossil fuels, particularly imported petroleum. Second, using solar energy can avoid the environmental problems associated with fossil fuel use. Third, as the technology continues to evolve, some types of solar systems will become costcompetitive in virtually all regions of the country.

DOE's Solar Industrial Applications Program is helping to provide the technology required for industry to realize

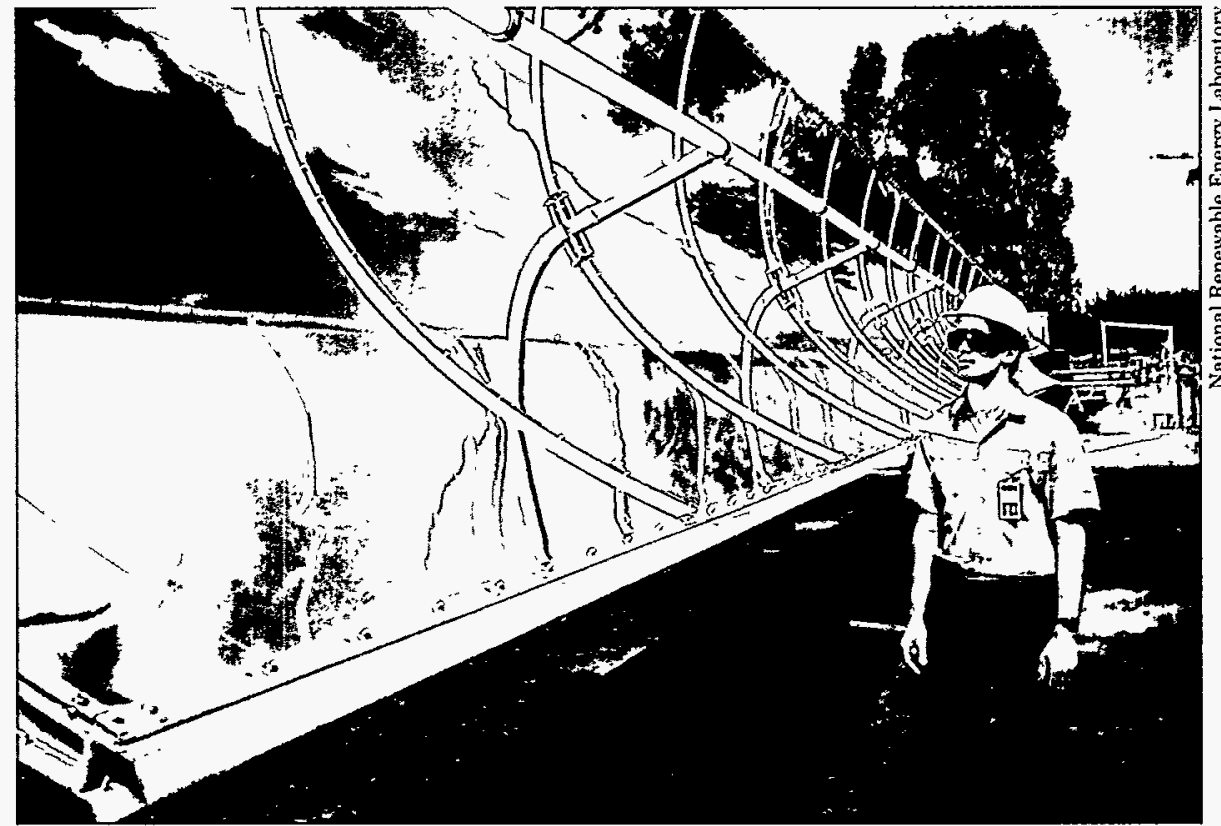

The solar detoxification process was field-tested at a Superfund site at Lawrence Livermore National Laboratory. The concentrated sunlight destroyed the volatile organic compounds in the groundwater. these advantages. By also

addressing the institutional and market barriers to solar-based technologies, the program can ensure that industry has the information it needs to consider

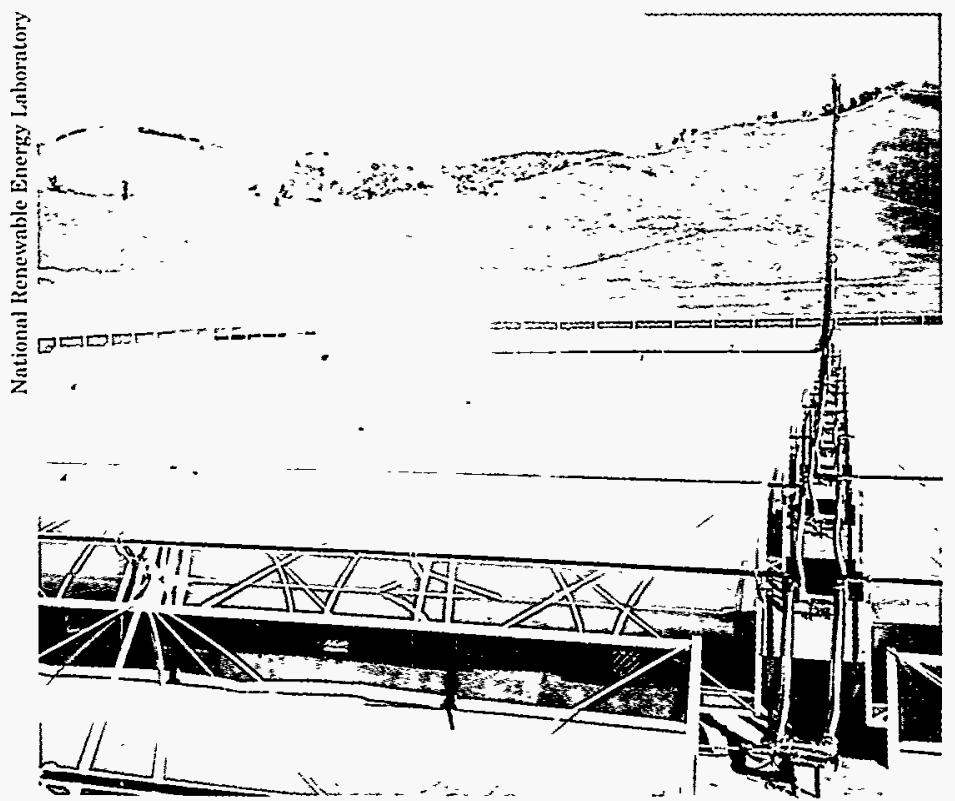

Solar process heat systems, such as this one at the California Correctional Institute in Tehachapi, California, are providing steam, hot water, and hot air to industries and commercial buildings across the nation. The DOE program is working with industry to address the remaining barriers to widespread application. solar applications. The program has three main elements: system and market assessments, technology development, and technology transfer.

\section{System and Market Assessments}

System and market assessments play a vital role in identifying the needs of industry and the opportunities for market penetration of the solar technologies. One recent study focused on the performance and cost of solar detoxification technology and examined regulatory issues affecting its commercial viability. The study identified as many as 24,000 potential sites requiring cleanup of groundwater or industrial waste water. About 5,000 of these are in the 13 southwestern states with the highest solar insolation.

A second study examined the near-and longterm market potential for solar process heating systems. The study concluded that with aggressive R\&D to lower costs, solar systems could provide as much as 4.0 exajoules ( 3.8 quadrillion Btu) of energy to manufacturing operations and 3.4 exajoules (3.2 quadrillion Btu) to commercial facilities in 2030 .

The program also recently sponsored studies by the National Research Council, the Massachusetts 
Institute of Technology, and SRI International to help identify opportunities for using highly concentrated sunlight in advanced industrial processes.

The three

\section{Industrial Applications of Solar Energy}

- Detoxifying contaminated water

- Destroying chemical wastes in soil

- Providing process heat

- Developing materials with enhanced properties

groups agreed that advanced materials applications should be the first target for program research and establishing industrial partnerships. As a result, two CRADAs for development of advanced materials were recently signed-one with Coors Ceramics and the other with Brush Wellman, Inc.

\section{Technology Development}

The market readiness of solar industrial technologies varies widely from solar process heat, which is ready for deployment in many locations, to advanced materials processing with the solar furnace, which is in the early stages of applied research. Solar detoxification is in between. Some detoxification systems are being used for field tests and demonstrations, while the enabling technology is being refined in the laboratory. Consequently, the SIA program encompasses a wide range of technology development activities.

For the process heat application, the program's emphasis is on working closely with the existing solar thermal industry to expand market penetration. One approach supports several prefeasibility studies, which allow small solar companies to bring together users, owners, and financing for process heat projects. The program also works with the states, the U.S.

Department of Defense, and other government agencies that can justify solar systems on the basis of their low life-cycle costs. These markets will provide the proving grounds for process heat systems.

Work on solar water detoxification is aimed at improving the cost and performance of the technology. One major development has been the field test conducted at a Superfund site at Lawrence Livermore National Laboratory. The test was cofunded by DOE's Office of Environmental Restoration and Waste Management. At the Lawrence Livermore site, a solar detoxification system was used to clean up trichloroethylene and other volatile organic compounds in the groundwater. Successfully completed in 1992, this field test was followed by another test at the Tyndall Air Force Base, Florida, to determine the efficiency of cleaning groundwater contaminated with a mixture of fuel oils. In 1993, these efforts will lead to industrial system designs, cost-shared by industry.

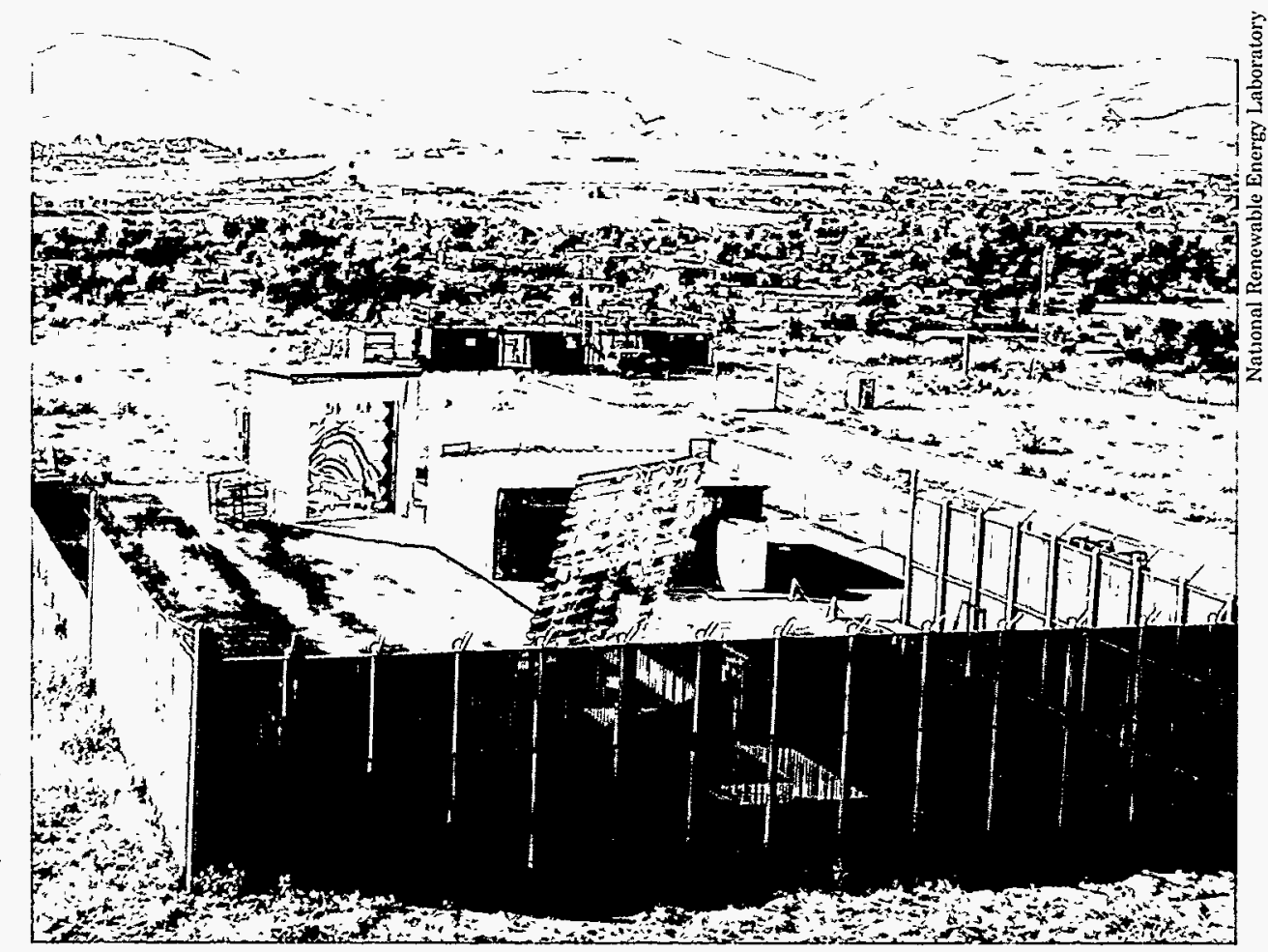

The high-flux solar furnace at the National Renewable Energy Laboratory can concentrate sunlight up to 50,000 times. Joint projects with industry are exploring options for making ceramic powders, ultrahard coatings, and other advanced materials. 
Soil detoxification is the subject of a joint project of DOE, the Department of Defense, and the EPA. The project will test a pilot-scale system for cleaning up aromatics, chlorinated aromatics, chlorinated solvents, and fuel oil. Initial tests at NREL will be followed by a field test at the Sierra Army Depot, California, and then a full-scale demonstration in 1995. This project will determine the feasibility of using solar energy to clean contaminated soil.

Progress on using concentrated sunlight to produce advanced materials is in earlier stages of research. Researchers for the CRADA with Coors Ceramics are conducting laboratory tests on a novel process for producing silicon-carbide powder for sintering applications. For the Brush Wellman CRADA, NREL scientists are conducting proof-ofconcept testing of a process for metallizing ceramic parts for advanced electronic packaging. In addition, laboratory-directed research is investigating advanced coatings-in particular, deposition of thin, diamond-like carbon layers for electronic and tribological applications.

\section{Technology Transfer}

Like the other WMM programs, technology transfer is an integral part of the SIA activities. The program joins with industrial partners in every area to conduct cooperative research and cost-shared demonstrations. In this manner, research is targeted at the technology industry needs. In addition, cooperation with industrial partners early in the development process results in effective technology transfer.

The program uses other techniques of transferring information and technology to industry including

- Working with local and state governments and other federal agencies

- Coordinating with industrial trade groups

- Sponsoring conferences, workshops, and exhibitions

- Publishing fact sheets, brochures, and reports. 


\section{A Partnership for Success}

By working together, DOE and industry are turning the challenge of waste material management into the reality of a cleaner, more energy-efficient nation.

DOE's Waste Material Management programs are making a difference. To date, seven new technologies are helping industry minimize or reuse its wastes. Together, these technologies are saving industry nearly 5 gigajoules ( 500 billion Btu) each year, worth more than $\$ 1$ million. With continued market penetration, annual savings from these technologies could grow to 47 petajoules ( 45 trillion Btu) in 2010 , worth more than $\$ 110$ million at today's prices. These savings will grow as some of the additional 35 projects currently under way and future successful research projects reach the marketplace. of $R \& D$ priorities developed with the help of industry advisors.

Early R\&D in the Solar Industrial Program provided the foundation for today's process heat industry, which delivers hot water, hot air, and steam in applica-

tions across the United States and abroad. Compared with the early systems of the late 1970s, today's systems deliver 5-10 times more energy per unit "We believe these partnerships enhance the ability of industry and governmental entities to work together to accomplish tasks that neither of us could accomplish alone."

- Ralph Ponce de Leon, Motorola, Inc.

of collector area

at one-tenth of the capital cost. The DOE program is working with the private sector to identify applications and to cost-share projects that will demonstrate to industrial energy managers that solar energy is an economical and reliable option for their energy needs.

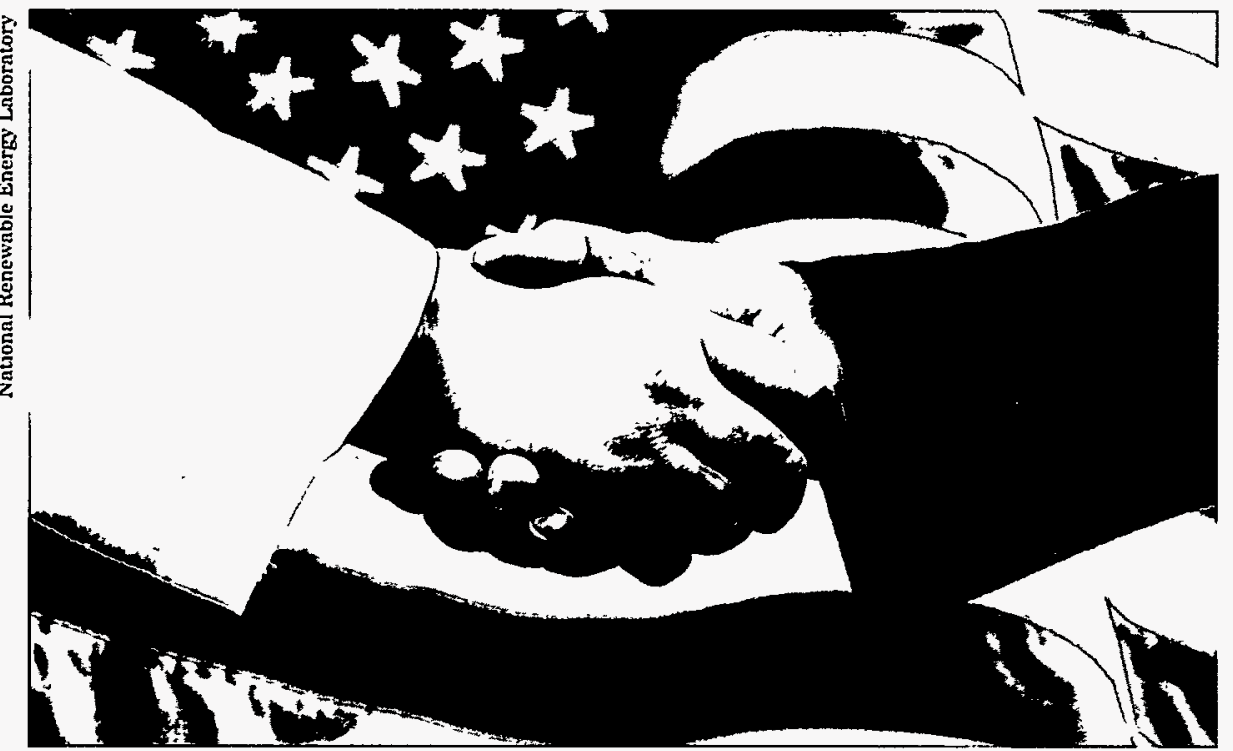

In the area of MSW, the program has worked with industry on both thermochemical and biological conversion processes. Several new technologies have resulted, greatly enhancing the effectiveness of anaerobic digestion, in particular. Future work within this program will be guided by a recent study
In addition, solar detoxification technologies are moving rapidly toward full-scale demonstration. And tests at the program's high-flux solar furnace recently set a new world record for solar concentration, providing a new, exciting tool for solar research.

These successes of the Waste Material Management Programs have come as a direct result of the interest, support, and involvement of industry. By maintaining this relationship with the private sector, the WMM Division strives to continue its record of achievement. In the process, industry will be more competitive, our nation's energy supply will be more secure, and our environment will be enhanced. 


\section{Insfî์ufion@l Analysis}

Legislative and Regulatory Incentives and

Disincentives to Industrial Waste Reduction

\section{Waste Utilization and Conversion Program}

\section{Industrial Waste Reduction Program}

\section{Dar̂a Collecrion}

Characterization of Major Data Sources for Industrial Waste Reduction

Simultaneous Waste and Energy-EnvironmentEconomic Tabulations (SWEET)

\section{Opporfuniß̌y Assessmenís}

\section{Industries}

R\&D Opportunities in the Chemical Users Industries R\&D Opportunities in the Petroleum Industries

\section{Teshnology R\&D}

Enclosed Silicon Production Furnace for Reducing Waste Gas Emissions

Dual-Cure Photocatalyst System for Coatings

Collection of Vapor-Liquid Equilibrium Data for Acid Gas-Mixed Amine Systems

Conversion of Industrial $\mathrm{H}_{2} \mathrm{~S}$ to Sulfur and Hydrogen

Reclaiming and Reusing Waste Water

Methanol Recovery Process

Control Strategies for Volatile Organic Compounds

Solvent Reduction through Self-Cleaning Soldering Process

Solvent Waste Minimization by Supercritical $\mathrm{CO}_{2}$ Cleaning

Hydrous Metal Oxide Catalysts for Production of Oxygenated Products

Electroplating Waste Minimization

Membrane Vapor Recovery Systems

National Industrial Competitiveness through Efficiency: Energy, Environment, and Economics ( $\mathrm{NICE}^{3}$, with $\left.\mathrm{EPA}\right)$

Solicitation for Waste Reduction in the Chemical Industry

\section{Technology Transfier}

Pollution Prevention in the Manufacturing Industries (cosponsoring American Institute of Chemical Engineering Symposium)

Inventory of organizations conducting R\&D in Industrial Waste Reduction and Minimization

\section{Teshnology R\&D}

Material Separation and Recycling

- Dezincing Galvanized Steel Scrap

- Purifying Scrap Aluminum

- Removing Lead from Red Metal

- Recycling Aluminum Salt Cake

- Recycling Plastics from Auto Shredder Residue

- Waste Tire Utilization

- Roofing Waste Utilization

- Waste Carpet Utilization

- Mixed Plastics Utilization

Remanufacturing/Demanufacturing

- Design for Recyclability

Conversion of Waste Components to Higher Value Materials

- Plastics from Potato Wastes

- Ethanol from Food Processing Wastes

- Biotechnology for Higher Value Chemicals from Waste

- Phenol Substitutes from Wood Wastes

- Higher Value Fermentation from Paper Mill Effluent

- Higher Value Fibers from Pulp and Paper Industry Wastes

- Biological Conversion of Waste Gases into Acetic Acid

- $\mathrm{CO}_{2}$ Utilization

Energy-Efficient Waste Treatment

- Freeze Crystallization Water Recovery

- Ceramic Membrane Separations of Oily Waste Water

\section{Tedhnology and Dafin Assessmenf}

Systems Analysis for Metals Recycling

Waste Data Project 


\section{Energy from Municipal Wastes Program}

\section{Dafa Collection and Analysis}

Collect Existing MSW Data

Develop and Maintain MSW Data Base

\section{Technology Development}

Thermochemical Technologies

- Develop New Pollution Control Strategies

- Improve Ash Management

- Improve Technology for Cofiring MSW with Sewage Sludge

Biochemical Technologies

- Enhance Landfill Gas Recovery

- Develop and Test Innovative Anaerobic Digestion Systems

\section{Institutional Assessments}

Assess Legal and Regulatory Issues

\section{Technology and Information Transfer}

Develop Information Transfer Plan

Communicate Results of Data Analysis and Assessment

\section{Solar Industrial Applications Program}

\section{Systems and Markef Assessments}

Water Detoxification

Soil Detoxification

Solar Process Heat

Advanced Materials Processing

\section{Technology Development}

Water Detoxification

- Catalyst Research

- Collector and Reactor Research

- Field Experiment at Tyndall Air Force Base, Florida

\section{Soil Detoxification}

-Tri-Agency Soil Detoxification Project (with Department of Defense and EPA)

Advanced Industrial Processes

- Furnace Development

- Industry Collaborations (with Coors Ceramics and Brush Wellman, Inc.)

\section{Technology Transfer}

Industrial Process Heat

- Support to the California Energy Commission

- Support to Federal Energy Managers

- Planning for Industry Demonstration Projects

Solar Detoxification

- Industry Collaboration and Support

- Working through Waste Water Management/Control Associations

Advanced Materials

- Industrial Collaborations

- Support for Solar Supplier Industry

\section{For Hore Information}

Waste Material Management Division CE-222

U.S. Department of Energy 1000 Independence Avenue, SW Washington, DC 20585

Mr. Kurt Sisson, Rm 5F-035

Division Director

Mr. Bruce Cranford, Rm 5F-043 Manager, Industrial Waste Reduction

Mr. Alan Schroeder, Rm 5F-043 Manager, Organic Waste Utilization

Mr. Stuart Natof, Rm 5F-035 Manager, Solid Waste Utilization

Mr. Simon Friedrich, Rm 5G-067 Manager, Energy from Municipal Waste

Mr. Frank Wilkins, Rm 5G-067 Manager, Solar Detoxification Applications

Mr. Cliff Carwile, Rm 5F-035

Manager, Solar Industrial Applications

Mr. Tom Foust, Rm 5F-035

Manager, Industrial Waste Reduction RD\&D 
Produced by the

Technical Information Program

National Renewable Energy Laboratory

1617 Cole Boulevard

Golden, CO 80401-3393

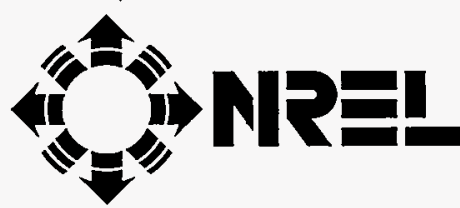

Operated by

Midwest Research Institute

for the

U.S. Department of Energy

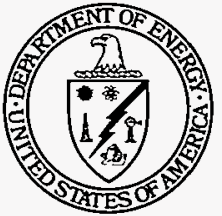

DOE/CH10093-189

DE93000054

May 1993

\section{NOTICE:}

This report is prepared as an account of work sponsored by an agency of the United States government. Neither the United States government nor any agency thereof, nor any of their employees, makes any warranty, express or implied, or assumes any legal liability or responsibility for the accuracy, completeness, or usefulness of any information, apparatus, product or process disclosed, or represents that its use would not infringe privately owned rights. Reference herein to any specific commercial product, process, or service by trade name, trademark, manufaclurer, or otherwise does not necessarily constitute or imply its endorsement, recommendation, or favoring by the United States government or any agency thereof. The views and opinions of authors expressed herein do not necessarily state or reflect those of the United States government or any agency thereof.

Printed in the United States of America

Available from:

National Technical Information Service

U.S. Department of Commerce

5285 Port Royal Road

Springtield, VA 22161

Price: Microfiche A01

Printed Copy $\mathrm{AO3}$

Codes are used in pricing all publications. The code is determined by the number of pages in the publication. Information pertaining to the pricing codes can by found in the current issue in the following publications which are generally available in most libraries: Energy Research Abstracts (ERA); Government Reports Announcements and Index (GRA and 1): Scientific and Technical Abstract Reports (STAR); and publication NTIS-PR-360 available from NTIS at the above address.

Printed with biodegradable ink on paper containing at least $50 \%$ waste paper 